\title{
The Synthesis of
}

\section{6-R-[1(Methylthio)-2,3,4,9-Tetrahydro-1H- $\beta$-Carbolin-1-yl] Cyanamides by the Interaction of Tryptamines with N-Cyanoimido-S, S-Dimethyldithiocarbonate}

\author{
Svetlana Mikhajlovna Medvedeva and Khidmet S. Shikhaliev \\ Faculty of Chemistry, Voronezh State University, Voronezh 394006, Russia
}

Received: July 06, 2013 / Accepted: August 10, 2013 / Published: December 25, 2013.

\begin{abstract}
It is studied the interaction of 5-substituted tryptamines with N-cyanoimido-S,S-dimethyldithiocarbonates. It is established that the reaction proceeds exhaustively under reflux in ethanol for 10-15 hours with elimination of one molecule of methylmercaptan, further cyclization passes not through the expected cleavage of the second molecule of methylmercaptan formation (6-R-2,3,4,9-tetrahydro-1H- $\beta$-carbolin-1-ylidene)cyanamides, and the accession of the hydrogen atom located at the carbon atom of the indole ring to the nitrogen atom of the imide groups and the carbon-carbon bond formation and the yield previously undescribed 6-R-[1(methylthio)-2,3,4,9-tetrahydro-1H- $\beta$-carbolin-1-yl] cyanamides.
\end{abstract}

Key words: Tetrahydro- $\beta$-carbolines, tryptamine, N-cyanoimido-S,S-dimethyldithiocarbonate, 6-R-[1(methylthio)2,3,4,9-tetrahydro-1H- $\beta$-carbolin-1-yl] cyanamide.

\section{Introduction}

Indefatigable interest to development of new approaches to synthesis of various derivatives of tetrahydro- $\beta$-carbolines is caused by well-known biological activity of the natural and synthetic compounds containing pharmaceutical activity indoles and tetrahydropyridines fragments $[1,2]$. In particular $\beta$-carbolines (including tetrahydro- $\beta$-carbolines) show antiinsurance, antipanic, antituberculosis and antitumor activity and stressprotective properties, therefore, are successfully used in the treatment of stress, depression [3-7].

In this connection, tetrahydro- $\beta$-carbolines are a perspective class of substances for the further research of medical products. Therefore creation of new

Corresponding author: Svetlana Mikhajlovna Medvedeva, Ph.D., associate professor, research field: chemistry of heterocyclic compounds. E-mail: smmedvedeva@rambler.ru. approaches which would allow expanding possibilities of designing of derivatives of it of some compounds is actual.

In nature, a fragment of tetrahydro- $\beta$ - carboline is the basis of some simple indole alkaloids (tryptoline, pinoline, tetrahydroharman, tetrahydrogarmin) in monoterpenoid indole alkaloids this fragment condensed with a carbo- and heterocycles (ajmalicine, akuamidine, vincarine, vincamine, erwin, nitrarin, yohimbine, reserpine) [8, 9]. However, with few exceptions [10-14], virtually nothing is known about psychopharmacology unannelation tetrahydro- $\beta$-carbolines. At the same time there is evidence [15-20] on the pharmacological activity of annelation tetrahydro- $\beta$-carbolines. In this regard, getting new multifunctional tetrahydro- $\beta$-carbolines is of interest in terms of their research pharmacological properties, on the other hand, the presence of several 
The synthesis of 6-R-[1(Methylthio)-2,3,4,9-Tetrahydro-1H- $\beta$-Carbolin-1-yl]Cyanamides by the Interaction 781 of Tryptamines with N-Cyanoimido-S,S-Dimethyldithiocarbonate

functional groups will allow annelated other heterocycles to fragment tetrahydro- $\beta$-carboline.

\section{Experiments}

\subsection{Materials}

All solvents and chemicals used in this work were analytical grade and used without purification.

\subsection{Characterization}

Control over the individuality of the reagents and the obtained compounds, as well as the progress of the reaction was monitored by TLC on Silufol UV-254. As eluent was used chloroform; the manifestation of chromatograms were in UV light and iodine vapor. $1 \mathrm{H}$ NMR spectra were recorded on the instrument Bruker AC-300 (300 MHz); internal standard, TMS, solvents, deyterodimethylsulfoxide. Mass-spectra were removed on the device LKB 9000 with the input of the substance directly in the ionizing source, the energy of ionizing electrons $70 \mathrm{EV}$.

2.3 General Method for the Synthesis of 6-R-[1-(Methylthio)-2,3,4,9-Tetrahydro-1H-ß-Carboli n-1-yl] Cyanamides 4a-d.

A mixture of $1 \mathrm{mmol}$ of the corresponding 5-R-tryptamine $1 \mathrm{a}-\mathrm{d}$ and $1.6 \mathrm{~g} \quad\left(\begin{array}{lll}1.1 & \mathrm{mmol}\end{array}\right)$ N-cyanoimido-S,S-dimethyldithiocarbonate in $20 \mathrm{ml}$ of ethanol is refluxed for 10-15 hours (control - TLC). The solvent was evaporated, the precipitate was filtered and recrystallized from THF. Received 6-R-[1-(methylthio)-2,3,4,9-tetrahydro-1H- 3 -carbolin1-yl]cyanamides 4 a-d.

[1-(methylthio)-2,3,4,9-tetrahydro-1H-ß-carbolin-1-y 1] cyanamide $4 \mathrm{a}$. Yield $95 \%$, mp $171-172{ }^{\circ} \mathrm{C}$. MS (EI, 70 ev) $\mathrm{m} / \mathrm{z}, \%$ : 258 (20, M+); 143 (100); 130 (65); 115 (5); 103 (5); 77 (5). ${ }^{1} \mathrm{H}$ NMR (300 MHz, DMSO-d 6 ) $\delta: 2.50$ $\left(3 \mathrm{H}, \mathrm{s}, \mathrm{SCH}_{3}\right) ; 2.90-3.00\left(2 \mathrm{H}, \mathrm{m}, \mathrm{CH}_{2}\right) ; 3.50-3.60(2 \mathrm{H}$, $\left.\mathrm{m}, \mathrm{CH}_{2} \mathrm{~N}\right) ; 6.98(1 \mathrm{H}$, ddd J = 8.1 Hz, $6.9 \mathrm{~Hz}, 1,1 \mathrm{~Hz} 6-\mathrm{H}$ or 7-H.); 7.12; (1H, ddd J = 8.1 Hz, 6.9 Hz, $1.1 \mathrm{~Hz} 6-\mathrm{H}$, or $7-\mathrm{H}.) ; 7.36(1 \mathrm{H}, \mathrm{d}, \mathrm{J}=8.3 \mathrm{~Hz}, 1.1 \mathrm{~Hz} 5-\mathrm{H}$ or $8-\mathrm{H})$; $7.56(1 \mathrm{H}$, д $\mathrm{J}=8.3 \mathrm{~Hz}, 1.1 \mathrm{~Hz} 5-\mathrm{H}$ or $8-\mathrm{H}) ; 7.18(1 \mathrm{H}, \mathrm{s}$,
$\left.\mathrm{NH}_{\text {pyrid. }}\right) ; 8,44$ (1H, br s, $\left.\mathrm{NH}\right) ; 10,86\left(1 \mathrm{H}\right.$, br s, $\left.\mathrm{NH}_{\text {indol. }}\right)$. Analysis: calc. for $\mathrm{C}_{13} \mathrm{H}_{14} \mathrm{~N}_{4} \mathrm{~S}$ : C 60.44, H 5.46, N 21.69, S 12.41. Found. C 60.54, H 5.49, N 21.60, S 12.48.

[6-fluoro-1-(methylthio)-2,3,4,9-tetrahydro-1H-ß-ca rbolin-1-yl]cyanamide 4b. Yield 74\%, mp $164-165^{\circ} \mathrm{C}$. MS (EI, 70 ev) m/z, \%: 276 (20, M+); 161 (100); 148 (65); 115 (5); 103 (5); 95 (5). ${ }^{1} \mathrm{H}$ NMR (300 MHz, DMSO-d 6 ) $\delta: 2 ., 46\left(3 \mathrm{H}, \mathrm{s}, \mathrm{SCH}_{3}\right) ; 2.86-2.96(2 \mathrm{H}, \mathrm{m}$, $\left.\mathrm{CH}_{2}\right)$; 3.50-3.66 (2H, m, $\left.\mathrm{CH}_{2} \mathrm{~N}\right) ; 7.02(1 \mathrm{H}, \mathrm{s}, 5-\mathrm{H}$.$) ;$ $7.36(1 \mathrm{H}, \mathrm{J}=8,3 \mathrm{~Hz}, 6-\mathrm{H}$ или $8-\mathrm{H}) ; 7.50(1 \mathrm{H}, \mathrm{J}=8.1$ $\mathrm{Hz}, 6-\mathrm{H}$ или 8-H); 7.24 (1H, s, $\left.\mathrm{NH}_{\text {pyrid. }}\right) ; 8.42$ (1H, br s, $\mathrm{NH})$; $10.92\left(1 \mathrm{H}\right.$, br s, $\left.\mathrm{NH}_{\text {indol. }}\right)$. Analysis: calc. for $\mathrm{C}_{13} \mathrm{H}_{13} \mathrm{FN}_{4} \mathrm{~S}$ : C 56.51, H 4.74, N 20.27, S 11.60. Found. C 56.60, H 4.79, N 20.20, S 11.68.

[6-chloro-1-(methylthio)-2,3,4,9-tetrahydro-1H-ß-c arbolin-1-yl]cyanamide 4c. Yield 68\%, mp 161-162 ${ }^{\circ} \mathrm{C}$. MS (EI, 70 ev) m/z, \%: 293 (20, M+); 178 (100); 165 (65); 115 (5); 138 (5); 112 (5). ${ }^{1} \mathrm{H}$ NMR (300 MHz, DMSO-d 6 ) $\delta: 2.48\left(3 \mathrm{H}, \mathrm{s}, \mathrm{SCH}_{3}\right) ; 2.90-2.96(2 \mathrm{H}, \mathrm{m}$, $\left.\mathrm{CH}_{2}\right)$; 3.52-3.68 (2H, m, $\left.\mathrm{CH}_{2} \mathrm{~N}\right) ; 7.14$ (1H, s, 5-H.); $7.42(1 \mathrm{H}, \mathrm{d}, \mathrm{J}=8.3 \mathrm{~Hz}, 6-\mathrm{H}$ or $8-\mathrm{H}) ; 7.54(1 \mathrm{H}, \mathrm{d}, \mathrm{J}=$ $8.1 \mathrm{~Hz}, 6-\mathrm{H}$ or $8-\mathrm{H}) ; 7.28\left(1 \mathrm{H}, \mathrm{s}, \mathrm{NH}_{\text {pyrid. }}\right)$; $8.46(1 \mathrm{H}$, br s, $\mathrm{NH}) ; 10.88\left(1 \mathrm{H}\right.$, br s, $\left.\mathrm{NH}_{\text {indol. }}\right)$. Analysis: calc. for $\mathrm{C}_{13} \mathrm{H}_{13} \mathrm{ClN}_{4} \mathrm{~S}$ : C 53.41, H 4.44, N 19.26, S 10.87. Found. C 53.35, H 4.50, N 19.15, S 10.93.

[6-methoxy-1-(methylthio)-2, 3, 4,9-tetrahydro-1Hcarbolin-1-yl] cyanamide 4d. Yield 87\%, mp 173-174 ${ }^{\circ} \mathrm{C}$. MS (EI, 70 ev) m/z, \%: 288 (20, M+); 173 (100); 160 (65); 115 (5); 133 (5); 110 (5). ${ }^{1} \mathrm{H}$ NMR $\left(300 \mathrm{MHz}, \mathrm{DMSO}-d_{6}\right) \delta: 2.48\left(3 \mathrm{H}, \mathrm{s}, \mathrm{SCH}_{3}\right) ; 2.92-3.00$ $\left(2 \mathrm{H}, \mathrm{m}, \mathrm{CH}_{2}\right) ; 3.46-3.68\left(2 \mathrm{H}, \mathrm{m}, \mathrm{CH}_{2} \mathrm{~N}\right) ; 3.82(3 \mathrm{H}, \mathrm{s}$, $\left.\mathrm{OCH}_{3}\right) ; 7.08(1 \mathrm{H}, \mathrm{s}, 5-\mathrm{H}.) ; 7.42(1 \mathrm{H}, \mathrm{d}, \mathrm{J}=8.3 \mathrm{~Hz}, 6-\mathrm{H}$ or $8-\mathrm{H}) ; 7.52(1 \mathrm{H}, \mathrm{d}, \mathrm{J}=8.1 \mathrm{~Hz}, 6-\mathrm{H}$ or $8-\mathrm{H}) ; 7.18(1 \mathrm{H}$, $\left.\mathrm{s}, \mathrm{NH}_{\text {pyrid. }}\right) ; 8.42(1 \mathrm{H}$, br s, NH); $10.90(1 \mathrm{H}$, br s,

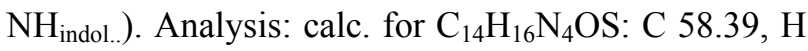
5.56, N 19.66, S 11.17. Found. C 58.30, H 5.60, N $19.45, \mathrm{~S} 11.10$.

\section{Results and Discussion}

\subsection{Synthesis and Characterization}

One of widespread methods of synthesis 
tetrahydro- $\beta$-carbolines cycle is interaction tryptamine with various cyclizationes agents. Wide enough application reaction of Pictet-Spengler in which basis interaction tryptamines with carbonyl compounds lies in particular has found $[21,22]$. In the given work in quality of cyclizationes agent has been chosen N-cyanoimido-S,S-dimethyldithiocarbonate. Given the reactivity of the starting compounds can be assumed that the interaction of tryptamine ([2-(1H-indol-3-yl)ethyl]amine)

with N-cyanoimido-S,S-dimethyldithiocarbonates should occur with the removal of two molecules of methylmercaptan. It is established that for all tryptamines 1 reaction easily passes at a boiling in ethanol and comes to the end during 10-15 $\mathrm{h}$. Obviously, interaction begins with amino group tryptamines attack methylthio group of reagent, with elimination molecules of methylmercaptan that gives intermediate 2-methyl- $N$-cyano- $N$-[2-(1H-indol-3-yl) ethyl] imidothiocarbamates 2. As we established, further cyclizatione passes not at the expense of expected elimination the second molecule of methylmercaptan and formations (6-R-2,3,4,9-tetrahydro-1H- $\beta$-carbolin-1-ylidene)cyan amide $\quad 3 \mathrm{~A}$ or its tautomer (6-R-4,9-dihydro-3H-ß-carboline-1-yl) cyanamide 3B, in summary joining of atom hydrogen at carbon atom being indole cycles to atom of nitrogen imido groups and short circuits carbon-carbon bond. Thus with the yield reaching $95 \%$, have been received 6-R-[1(methylthio)-2,3,4,9-tetrahydro-1H- $\beta$-carbolin$1-y l]$ cyanamides $4 \mathrm{a}-4 \mathrm{~d}$

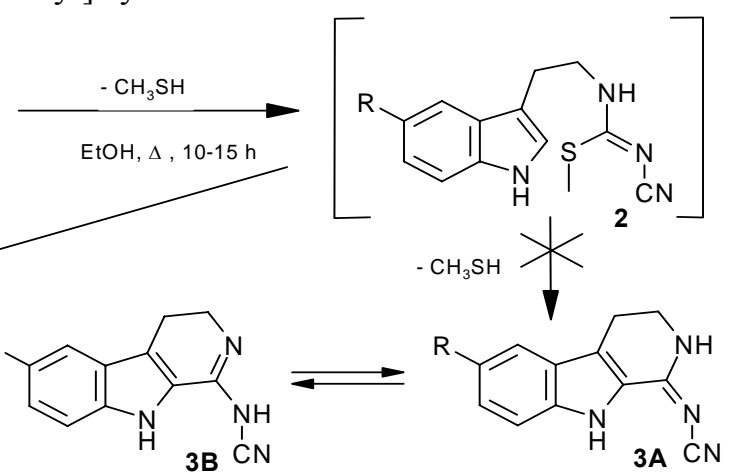

The structure of 6-R-[1(methylthio)-2,3,4,9tetrahydro-1H- $\beta$-carbolin-1-yl] cyanamides $4 \mathrm{a}-\mathrm{d}$ was proved by ${ }^{1} \mathrm{H}$ NMR spectroscopy and mass spectrometry. In ${ }^{1} \mathrm{H}$ NMR spectrum of these compounds there are signals of three protons methylmercapto-group in the form of singlets in the region of 2.46-2.50 ppm, two broadened singlet protons of amino-groups and $\mathrm{NH}$-protons indoles fragment in the areas of 8.28-8.46, and 10.86-10.92 ppm. The signal of the protons of amino-groups hydropyridines fragment is shifted into the weak field in the district 7.14-7.28 ppm, due to the influence of neighboring groups. Chemical shifts of aromatic protons and four protons of two methylene groups are shown in the relevant areas for these protons.

Mass spectrometric investigation showed that they give molecular ion peaks of low intensity $(I=20 \%)$.
Maximum intensity $(\mathrm{I}=100 \%)$ have the fragment ions formed by the removal of the neutral molecule methyl $\mathrm{N}$-cyanoimidothiocarbamate. Observed as intense peaks $(I=80 \%)$ indolylmethyl cations. All this implies greater stability compared to the indoles ring with hydropyridines.

Proceeding from structure of compounds 4, it is possible to assume possibility elimination of second molecule of methyl mercaptan, at the expense of atom of hydrogen endo-cycles or exo-cycles amino groups that should lead 4,9 -dihydro-3H- $\beta$-carbolin-1-ylcyanamide $3 \mathrm{~b}$ or it tautomer $3 \mathrm{a}$, accordingly. However, the elimination of the second mercapto-groups not occur even in harsh conditions: by reflux compounds 4 in alcohols (methanol, ethanol and butanol) with the addition of triethylamine as a catalyst, in dioxane in the presence 
of triethylamine, prolonged reflux ( $>50 \mathrm{~h}$.) in DMF leads to resinification of the reaction mass.

\subsection{Virtual Screening}

For all received compounds virtual screening by means of program PASS developed in IBMKh the Russian Academy of Medical Science (Moscow http://www.pharmaexpert.ru/PASSOnline/) is carried out. Computer forecasting has foretold with the probability exceeding $70 \%$ that compound $4 \mathrm{a}$ will 5-hydroxytryptamine release stimulant, antihypoxic, compound $4 \mathrm{~b}, 5$-hydroxytryptamine release stimulant, antineurotic, compound $4 \mathrm{c}$, antineurotic, phobic disorders treatment, compound 4d, 5-hydroxytryptamine release stimulant.

\section{Conclusions}

It is established that the interaction of tryptamines with N-cyanoimido-S,S-dimethyldithiocarbonates in boiling ethanol proceeds of abnormally with elimination one molecule of methylmercaptan, further cyclization passes not through the expected cleavage of the second molecule of methyl mercaptan, and the accession of the hydrogen atom located on the carbon atom of the indole ring to the nitrogen atom of the imide group and a circuit carbon-carbon bond formation with polyfunctional 6-R-[1(methylthio)-2,3,4,9-tetrahydro-1H- $\beta$-carbolin1-yl] cyanamides, not (6-R-2,3,4,9-tetrahydro$1 \mathrm{H}-\beta$-carbolin-1-ylidene) cyanamides.

\section{Acknowledgments}

This work was supported by the Ministry of Education and Science of the Russian Federation (contract № 02.G25.31.0007).

\section{References}

[1] V.I. Dulenko, I.V. Komissarov, A.T. Dolzenko, Y.A. Nikolyukin, $\beta$-Carbolines, Chemistry and neuroscience, in Naukova Dumka, Kiev, 1992, p. 216.

[2] B.E. Love, Synthesis of carbolines possessing antitumor activity in Top. Heterocycl. Chem., ed. By R. R. Gupta, Springer-Verlag Berlin Heidelberg 2 (2006)
93-128.

[3] F. Bracher, D. Hildebrand, L. Ernst, $\beta$-Carboline Alkaloids, V: Total Synthesis of the Antimicrobial Marine Alkaloid Eudistomin T. $\beta$-Carbolin-Alkaloide, 5. Mitt.: Totalsynthese des marinen Alkaloides Eudistomin T, Arch. Pharm. 327 (1994) 121-122.

[4] F. Bracher, D. Hildebrand, Pharmazie, ß-Carbolin-Alkaloide, 3. Mitt.: Synthese von Harmalacidin und Strychnocarpin 48 (1993) 695.

[5] K. Huber, O. Kast, F. Bracher, A versatile synthesis of 3-substituted 4-cyano-1,2,3,4-tetrahydro-1-oxo- $\beta$ carbolines, Synthesis 22 (2010) 3849-3854.

[6] J.D. Winkler, J.M. Axten, The first total syntheses of ircinol A, ircinal A, and manzamine A and D, J. Am. Chem. Soc. 125 (1998) 6425-6426.

[7] A.A. Vinnik, V.V. Nesteruk, P.O. Fedichev, M.N. Kholin, B-carbonyl derivatives having anti-tuberculosis activity, RU Patent, WO2011099886 A1 (2010).

[8] M.V. Kisakurek, A.J.M. Leeuwenberg, M. Hesse, Alkaloids: Chemical and Biological Perspectives, ed. by S. W. Pelletier, v. 1, N. Y., 1983, pp. 211-377.

[9] A.J. Scott, S. Lee, M.G. Culver, W. Wan, T. Hirata, F. Guéritte, et al., Indole Alkaloid Biosynthesis, Heterocycles 15 (2) (1981) 1257-1274.

[10] Y. Kawashima, A. Horiguchi, M. Taguchi, Y. Tuyuki, Y. Karasawa, H. Araki, et al., Synthesis and pharmacological evaluation of 1,2,3,4-tetrahydro-beta-carboline derivatives, Chem. Pharm. Bull. (Tokyo) 43 (1995) 783-787.

[11] M.M. Airaksinen, B.T. Ho, R. An, D. Taylor, Major pharmacological effects of 6-methoxytetrahydro-beta-carboline, a drug elevating the tissue 5-hydroxytryptamine level, Arzneimittelforschung 28 (1978) 42-46.

[12] H. Rommelspache, H. Kauffmann, C. Heyck Cohnitz, H. Coper, Pharmacological properties of tetrahydronorharmane (Tryptoline), J. Naunyn-Schmiedeberg's Arc. Pharm. 298 (1977) 83-91.

[13] M.M. Airaksinen, J.T. Huang, B.T. Ho, D. Taylor, K. Walker, The Uptake of 6-Methoxy-1,2,3,4-Tetrahydro$\beta$-carboline and its Effect on 5-Hydroxytryptamine Uptake and Release in Blood Platelets, Acta Pharmacol. Toxicol. 43 (1978) 375-380.

[14] G.M. Badger, A.F. Beecham, Isolation of Tetrahydroharman from Petalostyles labicheoides, Nature 168 (1951) 517-518.

[15] K.L. Jansen, C.J. Prast, Ethnopharmacology of kratom and the Mitragyna alkaloids, J. Ethnopharmacol 23 (1988) 115-119.

[16] E.J. Shellard, The Alkaloids of Mitragyna with Special Reference to those of Mitragyna Speciosa, Korth. UNODC, Bulletin on Narcotics, 1974, pp. 41-55.

[17] S. Siddiqui, R.H. Siddiqui, Chemical examination of the 


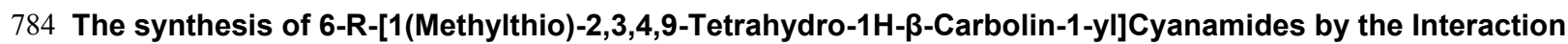
of Tryptamines with N-Cyanoimido-S,S-Dimethyldithiocarbonate

roots of Rauwolfia serpintina, J. Indian Chem. Soc. 8 (1931) 667-680.

[18] J.D. Curb, R.J. Hardy, D.R. Labarthe, N.O. Borhani, J.O. Taylor, Reserpine and breast cancer in the hypertension detection and follow-up program, Hypertension 4 (1982) 307-311.

[19] M.J. Millan, A. Newman-Tancredi, V. Audinot, D. Cussac, F. Lejeune, J.P. Nicolas, et al., Agonist and antagonist actions of yohimbine as compared to fluparoxan at alpha(2)-adrenergic receptors (AR)s, serotonin $\quad(5-\mathrm{HT})(1 \mathrm{~A}), \quad 5-\mathrm{HT}(1 \mathrm{~B}), \quad 5-\mathrm{HT}(1 \mathrm{D}) \quad$ and dopamine $D(2)$ and $D(3)$ receptors, Significance for the modulation of frontocortical monoaminergic transmission and depressive states, Synapse 35 (2000) 79-95.

[20] P. Cook, I. James, Cerebral vasodilators, New England Journal of Medicine 305 (1981) 1560-1564.

[21] R.A. Abramovich, I.D. Spenser, The carbolines, Adv. Heterocycl. Chem. 3 (1964) 79-207.

[22] F. Ungemach, J. Cook, The spiroindolenine intermediate: A review, Heterocycles 9 (1978) 1089-1119. 